\title{
Technical English Problems in Workplace: A Case Study of ESP - Sudanese Graduate Students
}

\author{
Dr. Fadiel Mohammed Musa
}

Assistant Professor

Department of English Language

Nahda College

Omdurman, Khartoum, Sudan

fadielmoosa@yahoo.com

\begin{abstract}
This paper aims at investigating technical English taught in Sudan higher education to find out whether the ESP meets the students' needs when they join vocations and workplace. Twenty five students majored in different specializations participated in the study. They are graduates of different Sudanese Universities and Colleges.

To yield more insights and more description, the following are the questions of the study:

1. How does English for Specific Purpose (ESP) courses meet students' needs in their studies at colleges? 2. Do ESP courses prepare students to the workplace?

The results indicate that the majority of the participants were not satisfied with their courses they learned at colleges when they were students because those courses did not meet their needs in workplaces.
\end{abstract}

Keywords: EGP, ESP, long-term, short-term

Introduction:

Technical English has a pivotal role in transferring technical language to learners of L2. Technical or English for Specific Purpose (hereafter ESP) helps students to focus on specific language skills that suit the learner's needs because ESP offers students topics to meet and trains 
them in their major. The need for English for Specific Purposes appeared in the 1960s and it focused on students' need (Lindahl 2015).

The aim of this paperis to find out to what extent does the current ESP taught in some Sudanese colleges equips graduate students and prepares them in workplace. In other words, whether students can read and write texts related to what they need, for example manuals, filling in job forms and replying telephones calls.

\section{1. Objectives of the Study}

The study seeks to find answers to the following questions:

a- Does present English for Specific Purpose (ESP) courses meet students' needs in their studies at colleges?

b- To what extent do these courses prepare students to workplace?

\section{Literature Review}

The wide spread of technology today is one reason why ESP is needed. Another reason is because English has become the lingua franca of technology. Lindahl (2015, p. 23) states that "ESP is needed because of the scientific, economic and technical boom recently." Therefore, university level students should study English for General Purpose (hereafter EGP) as well as ESP to equipthem with the knowledge of the new technology. Fortunately, Sudanese students study English for more than ten years in General Education. They are familiar with EGP, but ESP is a new field for them when they come to university. These students are streamed in different specializations, for instance medicine, pharmacology, engineering, IT, management etc....

Unfortunately, English language lecturers face the fact that more than 60 students from different fields of specializations are grouped together in one lecture room in some colleges. This 
cripples and grapples to achieve the major aims of ESP teaching. ESP is supposed to tackle short-term and long-term problems. Rapoport et al (2010, p. 5) point out that there are two main aims of ESP learning. Firstly in the short-term learners should know how to read, understand texts and build strategies of solving reading problems. Secondly, in the long-term learners could read and understand scientific texts they face after graduation. To avoid these problems, it is necessary to teach learners ESP aligned with their specializations at university level to meet requirement of employees in the future. Thivvyah and Nor $(2013$, p. 11) point out that "Introducing English as a medium of instructions (EMI) in the teaching and learning is to enable students to keep up with the current technological development mainly available in English." Thus; ESP is important to build knowledge for today's academic studies and future skills for students' professions and vocations.

\subsection{Problems}

In 2012 the researcher was teaching first year undergraduate Electronic Engineering students. He used to take some manuals of different electric items. In group discussions students showed insufficient understanding of the instructions, operation, caution, or precautions. Then the coming years whenever the researcher taught ESP, (e.g., 2014 Administrative Sciences students), the same problem was noticed among different disciplines. This incapability of ESP understanding led the researcher to inquire students' knowledge of ESP.

\section{1. 1. Grouping}

Here are two methods of grouping students.In general, students are mainly grouped according to the placement test result which is based on general English (EGP) and not on English for Specific Purpose (ESP). Secondly, students are not grouped according to their major. Instead, one group consists of students from different fields and specializations. 


\section{2. 2.Large Number of Students}

Another difficulty is the big number of students in one group. In some universities there are more than hundred students in one group. In these groups students miss the opportunity of discussion and interaction, so instructors tend to use presentation activity only (mono-speaking).

\section{2. 3.Lack of Time}

English skills need practice, but the number of hours allocated forboth ESP and general English are usually not sufficient; in most colleges only two hours a week. As ESP is one of the university requirements, the syllabus usually does not focus on topics which are related to students' majors.

2. 2. 4. Syllabus

In fact, most of the courses taught are related to English for General Purposes (EGP) containing combined texts from different sources focusing on vocabulary and grammar. The researcher experienced lecturing English syllabus in some colleges which was entirely built on grammar and general vocabulary to engineering students. Maruyama (2006, p. 225) argues that most of the books are written by English literature majors who concentrate on everyday language.

\section{3. Related Studies}

Lindahl (2015) conducted a study to find out how, and in what ways, did vocational English is a part of English language teaching in the'Building and Constructions Programmes' in Sweden. The researcher usedtwo instruments: questionnaire and interview. The results revealed that teachers and inspectorate had positive attitudes towards English, but the English content and methods needed more discussions. The results also indicated that the students of technical programmes had "low results on the national test for the course in English ..." 
Nassief (2016), conducted a study to investigate ESP course designed to first year students in college of Law at Alneelien University. The researcher claims that the course legal content. It had only grammatical rules which were not related to law.

Nor (2013),conducted a study to examine instructors' perceptions about teaching of technical English courses at polytechnic in Malaysia. A questionnaire was used to collect data for the study. The questionnaire contained four aspects: lecturers' readiness, attitudes, problems, and training needs. Seventy five technical lecturers were involved in the study. The results indicated that lecturers wereunprepared to teach technical English courses. Findings also showed that lecturers needed more training to teach technical English.

In his study Thi (2016) on teaching English for specific purposes at Vietnam Universities, the researcher states that "Students after graduation do not meet English requirements of employers, so unemployment becomes more serious." The researcher did an experiment to discover factors having impact on teaching ESP. the study involved teachers and students. The results indicated that students' standard of English, both general English and ESP, was below the minimum level.

This study is different. All above study respondents were students. Hence, the participants of the present study were graduates who joined jobs in either government or private sector. The researcher visited the participants in their workplaces after graduation.

\section{Methodology}

The subjects of this study are graduates who hold different posts and work for different companies. They have studied at different colleges in Sudan. A Questionnaire was used as a tool for the study.Thirty question papers were distributed to the participants. The questions were grouped into two categories: a) ESP English courseat colleges and b)their outcome at workplace. 
Twenty-five participants attended the questionnaire. Receiving the respondents' answers, they were computed, analyzed and results were displayed.

\section{Results, Discussions and Findings}

With respect of the questionnaire results the two areas where participants faced problems; course problems at colleges and problems at workplace, are discussed below . a- Course Problems at College

This is the result of the statements directed to participants. The statements were divided into two categories: the course problems faced the participants at colleges and the problems they face now at workplace.

Table 1 represents problems faced participants at their colleges.

\begin{tabular}{|c|c|c|c|}
\hline Statements & agree & neutral & disagree \\
\hline \multicolumn{4}{|l|}{ a. Course Problems at college } \\
\hline \multirow{2}{*}{$\begin{array}{l}\text { 1. I have problems in reading technical textbooks in } \\
\text { English. }\end{array}$} & 8 & 6 & 5 \\
\hline & $41.1 \%$ & $31.6 \%$ & $26.3 \%$ \\
\hline \multirow{2}{*}{$\begin{array}{l}\text { 2. The problems in understanding English I have are due to } \\
\text { difficulty of technical language. }\end{array}$} & 10 & 3 & 7 \\
\hline & $50 \%$ & $35 \%$ & $15 \%$ \\
\hline \multirow[t]{2}{*}{ 3. The ESP courses cover all what I need. } & 7 & 5 & 8 \\
\hline & $35 \%$ & $25 \%$ & $40 \%$ \\
\hline \multirow[t]{3}{*}{ 4. There is no emphasis of ESP on my field. } & 11 & 7 & 0 \\
\hline & $61.1 \%$ & $38.9 \%$ & $00 \%$ \\
\hline & 10 & 4 & 6 \\
\hline
\end{tabular}




\begin{tabular}{|l|l|l|l|}
\cline { 2 - 3 } 5. The same ESP courses are taught to different & $50 \%$ & $20 \%$ & $30 \%$ \\
\hline specialization (majors). & & & \\
\hline 6. I do not find solution to technical language problems I & 10 & 1 & 9 \\
have. & $50 \%$ & $05 \%$ & $45 \%$ \\
\hline 7. There are sufficient terminologies of ESP included in my & 8 & 7 & 4 \\
\hline reading course. & $42.1 \%$ & $36.8 \%$ & $21.1 \%$ \\
\hline 8. It is important to have a preparatory English programme & 19 & 1 & 0 \\
\hline for first year students. & $95 \%$ & $05 \%$ & $00 \%$ \\
\hline
\end{tabular}

a) Table 1 representscourse problems faced participants at colleges.

1. 'I have problems in reading technical textbooks in English.' Eight out of twenty students (41.1\%) agreed that they have problems when they read technical textbooks. $31.6 \%$ were neutral, whereas $26.3 \%$ disagreed. This indicates that $41.1 \%$ of participants' present problems were originated since they were at colleges, whereas, only $26.3 \%$ of the participants could understand technical English when they were students.

2. In their response to statement two 'The problems in understanding English I have are due to difficulty of technical language.', ten respondents agreed that they faced problems to understand technical language; i.e.,: $(50 \%) .7$ (35\%) were neutral. Three out of twenty (15\%) could understand the technical language. It is obvious that only few participants could understand language of technology which is important in today's careers.

3. 'The ESP courses cover all what I need.' 7 (35\%) agreed, 5 (25\%) were neutral. Eight participants (40\%) disagreed with the statement above.

4. 'There is no emphasis of ESP on my field.' Eleven participants $(61.1 \%)$ mentioned that the courses they studied had little concentration on their majors. 7 (38.9\%) were neutral. 
5. 'The same ESP courses are taught to different specialization (majors). ' Half of the participants; i.e.: $10(50 \%)$ the courses they studied were for all specializations. 4 (20\%) were neutral whereas $6(30 \%)$ disagreed.

6. 'I do not find solution to technical language problems I have.' $50 \%$ could not have answers to their problems related to technical language. Only one participant was $1(05 \%)$ neutral, while a considerable number of respondents mentioned - 9 (45\%) - that they could find solution to their problems.

\section{7. 'There are sufficient terminologies of ESP included in my reading course.'}

Eight respondents (42.1\%) agree, 7 (36.8\%) neutral, 4 (21.1\%) disagree to statement seven. 8. The majority of the participants; nineteen (95\%), welcomed the statement 'It is important to have a preparatory English programme for first year students.' Only one (05\%) is neutral, meanwhile no one opposed the statement.

Table 2 (below) represents the statements related to technical English and problems face the participants at workplace.

9. In response to statement nine'I have difficulties in understanding terminologies of ESP.', a significant number of respondents, twelve (60\%), agreed with this statement. Seven (35\%) were neutral. Only one participant $(05 \%)$ disagreed.

10. Statement ten'Usually I find difficulties in reading ESP because of text complexity. 'indicates eleven $(55 \%)$ agreed. This reveals that the same problem continues with many participants since they were students. Seven (35\%) were neutral, 2 (10\%) did not find difficulties in reading ESP materials.

11.Among twenty participants, sixteen $(84.2 \%)$ referred their present problems to the poor language knowledge. Simultaneously this is related to ineffective college courses. No one 
opposed the statement'I have encountered problems of ESP because of my language background knowledge.' About three (15.8\%) were neutral.

12. Understanding of structure as shown in statement twelve'I sometimes cannot understand texts of ESP related to my field because of the sentence structure.' is of big problem for 60\% (12) of the participants. Four were (20\%) neutral, while same number $(20 \%)$ disagreed.

13.Eight respondents (40\%) agreed that 'The ESP courses have prepared me for the workplace.' Five participants (25\%) were neutral. A good number of participants 35\% (seven) find problems

\begin{tabular}{|c|c|c|c|}
\hline b. Workplace & agree & neutral & Disagree \\
\hline 9. I have difficulties in understanding terminologies of & 12 & 7 & 1 \\
\hline ESP on my field studies. & $60 \%$ & $35 \%$ & $05 \%$ \\
\hline 10. I find difficulties in reading ESP because of text & 11 & 7 & 2 \\
\hline complexity. & $55 \%$ & $35 \%$ & $10 \%$ \\
\hline 11. I usually have encountered problems of ESP because & 16 & 3 & 0 \\
\hline of my language background knowledge. & $84.2 \%$ & $15.8 \%$ & $00 \%$ \\
\hline 12. I sometimes cannot understand texts of ESP related & 12 & 4 & 4 \\
\hline to my field because of the sentence structure. & $60 \%$ & $20 \%$ & $20 \%$ \\
\hline 13. The ESP courses have prepared me for the & 8 & 5 & 7 \\
\hline workplace. & $40 \%$ & $25 \%$ & $35 \%$ \\
\hline
\end{tabular}

in their workplace.This is obvious that more efforts are needed to equip students for future job market.

Table 2 Problems at Workplace c- Findings 
Findings show that college and university ESP courses do not meet learners' needs and consequently do not prepare graduates for futurejob market.

The results and discussions above lead to the answers of the research questions:

1. How does English for Specific Purpose (ESP) courses meet students' needs in their studies at colleges? and2. Do ESP courses prepare students to the workplace?

By analyzing the first eight statements related to college courses, the courses taught at colleges do not meet the learners' need. About $41.1 \%$ suffered from when theyread technical language. $50 \%$ of participants involved in the study find difficulty to understand technical language. While $61.1 \%$ agreed that the courses taught are havingno emphasis of ESP on their specialization and their fields of studies.Consequently, 50\% of the respondents said that they have no solution to technical language problems.

Thus; the majority of 95\% demand preparatory English programme courses; i.e., foundation courses, for first year students.

The answer to the first question from analysis indicates that the present ESP courses offered by Sudan universities and colleges do not meet learners' needs.

The participants' answers to the second question of the study: "Do ESP courses prepare students to the workplace?" reveal big gap between what is taught at colleges and what is needed in workplace.

Only $35 \%$ have found themselves prepared for the workplace. In response to the statement aboutdifficulties in understanding terminologies of ESP, $60 \%$ said that they cannot understand terminologies on their specializations. Still in workplaces these graduates find difficulties in reading ESP; about $84.2 \%$ relate the weakness to their language background knowledge. 


\section{d- Conclusions}

The development of technology combined with English being as world lingua franca,has made ESP necessary. It is important tostrengthen students' knowledge and abilities in learning ESP while they are in colleges to cope with workplace necessaries in the future. The researcher investigated current ESP courses offered by Sudanese universities and their relevance to graduates' needs in workplace. Responds to the questionnaire notably showed that participants face real lack of ESP knowledge.The study shows that there is a need for reviewing courses offered by universities and colleges to match the needs of future jobs for the graduates. There is a need for both: ESP to assist learners in their majors and English for General Purposes (EGP) for everyday communication.This research suggests that offering foundation ESP and EGP courses apart from university requirements- are necessary for the university and college newly intake students. 


\section{References}

Lindahl, K., 2015, Vocational English in Policy and Practice, University of Gothenburg Maruyam, H., 2006, Difficulties in Teaching Technical English in Japan, Japan Research Institute for English Culture

Nassief, M., 2016, Evaluation of ESP Course Designed to First Year, Sudanese Law

Students, Alneelain University from the Students' Perspective, Journal of Humanities, Vol .17. No. 4, December (2016)

Nor, R.,Technical Instructions in English: Voices of Technical Lecturers, Journal of Technical Education and Training (JTET), Vol. 5, No.1, June 2013

Palurović, L., 2014, Teaching Technical English: Difficulties and Solutions Revised, 5th International Conference, Faculty of Technical Sciences, 30-31 ${ }^{\text {st }}$ May 2014

Quoc, T., 2018, The Difficulties in ESP Reading Comprehension Encountered by EnglishMajored Students, Ho Chi Minh City University of Technology (HUTECH)

Rapoport, A. The Meaning of The Built Environment: A Non-Verbal Communication Approach. Tucson: The University of Arizona Press, 2010.

Riabtseva, E. V., Some Problems of Teaching English for SpecialPurposes to Students of Technical Specialties at University Level, ТГТУ. 2006. Том 12. No. 16. Transactions TSTU.

Thivviyah, S., 2013, Technical Instructions in English: Voices ofTechnical Lectures, Vol. 5, No.1| June 2013| ISSN 2229-8932 Journal of Technical Education and Training (JTET) Thị, N. and Thị, P., 2016, Difficulties in Teaching English for Specific Purposes: Empirical Study at Vietnam Universities, Published by Canadian Center of Science and Education, Higher Education Studies; Vol. 6, No. 2; 2016. 
DOI: https://doi.org/10.24113/ijohmn.v6i6.209

Williams, C. Research Method. Journal of Business and Economic Research (JBER) 5(3). 2011. 